\title{
Pseudomonas panacis sp. nov., isolated from the surface of rusty roots of Korean ginseng
}

Correspondence

Jongsik Chun

jchun@snu.ac.kr

\section{Yoon-Dong Park, ${ }^{1} \dagger$ Hyang Burm Lee, ${ }^{1} \dagger$ Hana $\mathrm{Yi}_{1}{ }^{1}$ Youngjun Kim, ${ }^{2}$ Kyung Sook Bae, ${ }^{3}$ Jae-Eul Choi, ${ }^{4}$ Hack Sung Jung ${ }^{1}$ and Jongsik Chun ${ }^{1}$}

\author{
${ }^{1}$ School of Biological Sciences, Seoul National University, Kwanak-gu, Seoul 151-742, \\ Republic of Korea \\ ${ }^{2}$ Division of Biotechnology, The Catholic University of Korea, Puchon 420-743, \\ Republic of Korea \\ ${ }^{3}$ Korean Collection for Type Cultures, Korea Research Institute of Bioscience and \\ Biotechnology, Taejon 305-600, Republic of Korea \\ ${ }^{4}$ Department of Crop Science, College of Agriculture and Life Science, Chungnam National \\ University, Taejon 305-764, Republic of Korea
}

Since its creation by Migula (1894), the genus Pseudomonas has been studied with increasing interest because of the importance of its members in medical, food and environmental microbiology as well as phytopathology. Members of the genus Pseudomonas are widely distributed in agricultural soils and have a variety of functions relating to the decomposition of organic matter, the promotion of plant growth and pathogenic effects (Palleroni, 1993). During the study of the induction of bacterial rusty roots, a bacterial strain, designated CG20106 ${ }^{\mathrm{T}}$, was isolated from Korean ginseng (Panax ginseng C. A. Meyer) and examined using a polyphasic taxonomic approach. On the basis of the polyphasic evidence, strain CG20106 ${ }^{\mathrm{T}}$ represents a novel species of the genus Pseudomonas.

A surface-tissue sample of rusty root lesions of Korean

tThese authors contributed equally to this work.

The GenBank/EMBL/DDBJ accession number for the 16S rRNA gene sequence of strain CG20106 ${ }^{\top}$ is AY787208.

Transmission electron micrographs of Pseudomonas panacis sp. nov. CG20106 $^{\top}$ and Pseudomonas azotoformans KCCM 35487 ${ }^{\top}$ are available as a supplementary figure in IJSEM Online. ginseng $(1 \mathrm{~g})$ was collected under aseptic conditions and then suspended in $1 \mathrm{ml}$ sterile water with mixing for $30 \mathrm{~min}$. The suspension $(0.5 \mathrm{ml})$ was spread on nutrient agar (NA; Difco) and incubated for 1 day at $30^{\circ} \mathrm{C}$. Strain CG20106 ${ }^{\mathrm{T}}$ was isolated and routinely cultured on NA at $30^{\circ} \mathrm{C}$. A poorly characterized reference strain, Pseudomonas azotoformans KCCM $35487^{\mathrm{T}}$ (Anzai et al., 1997), was also cultured on NA at $30^{\circ} \mathrm{C}$ and analysed in this study.

Bacterial DNA preparation and PCR amplification and sequencing of the $16 \mathrm{~S}$ rRNA gene sequence were carried out as described previously (Chun \& Goodfellow, 1995). The resulting sequence of strain CG20106 ${ }^{\mathrm{T}}$ was aligned manually against sequences obtained from GenBank. Phylogenetic trees were inferred from regions available for all sequences (positions 6-1451; Escherichia coli numbering system) using the Fitch-Margoliash (Fitch \& Margoliash, 1967), maximum-likelihood (Felsenstein, 1993), maximum-parsimony (Fitch, 1972) and neighbour-joining (Saitou \& Nei, 1987) methods. Evolutionary distance matrices were generated according to Jukes \& Cantor (1969). The resulting tree topologies were evaluated in bootstrap analyses (Felsenstein, 1985) based on 1000 resamplings. The alignment and phylogenetic analyses were carried out using the jPHYDIT 
program (available at http://chunlab.snu.ac.kr/jphydit) and PAUP 4.0 (Swofford, 1998), as described previously (Chun et al., 2000).

Preliminary sequence comparisons with 16S rRNA sequences held in GenBank indicated that our isolate was closely related to the genus Pseudomonas. The newly determined sequence was then aligned manually against representatives of pseudomonads, using information on bacterial 16S rRNA secondary structures. Strain CG20106 ${ }^{\mathrm{T}}$ showed the highest 16S rRNA gene sequence similarity to Pseudomonas migulae CIP $105470^{\mathrm{T}}$ (99.3\%), followed by Pseudomonas veronii CIP $104668^{\mathrm{T}}(99 \cdot 0 \%)$, Pseudomonas cedrina CFML $96-198^{\mathrm{T}}(98.6 \%)$ and Pseudomonas azotoformans IAM $1603^{\mathrm{T}}(98 \cdot 6 \%)$. This relationship was also recovered in phylogenetic trees. Our ginseng isolate was clearly affiliated with the Pseudomonas fluorescens group and formed a distinct phyletic line within the clade which contained the type strains of Pseudomonas migulae, Pseudomonas cedrina, Pseudomonas azotoformans, Pseudomonas gessardii, Pseudomonas synxantha and Pseudomonas mucidolens (Fig. 1). The branching position of strain CG20106 ${ }^{\mathrm{T}}$ within this clade was relatively stable, according to the multiple tree-making algorithms used in this study, in spite of the low bootstrap value (55\%). Strain CG20106 formed the deepest branch of the clade in the maximumparsimony tree, but was recovered as a sister group of the

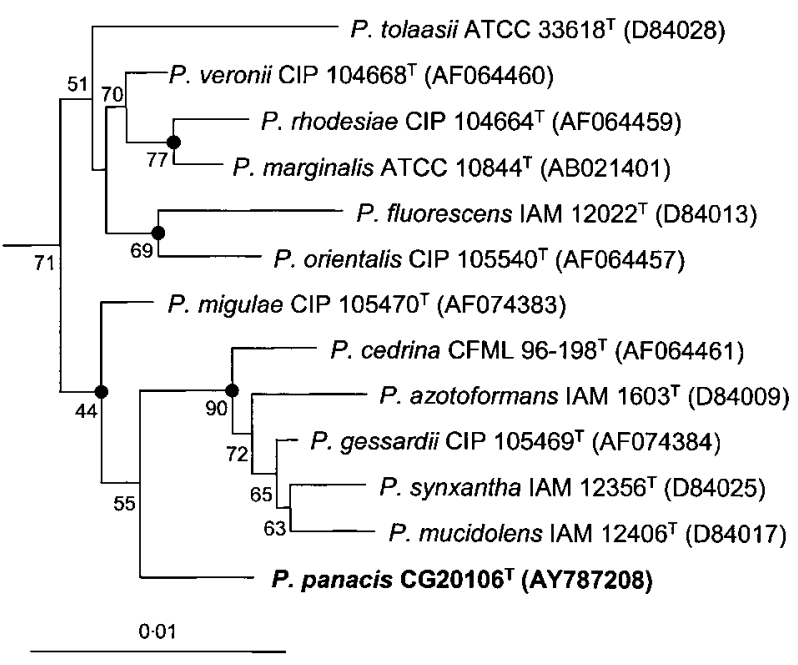

Fig. 1. Neighbour-joining tree, based on almost-complete $16 \mathrm{~S}$ rRNA gene sequences, showing relationships among strain $\mathrm{CG}^{20106}{ }^{\top}$ and closely related members of the genus Pseudomonas. Percentages at nodes are levels of bootstrap support based on neighbour-joining analyses of 1000 resampled datasets; solid circles indicate that the corresponding nodes (groupings) are also recovered in Fitch-Margoliash, maximum-likelihood and maximum-parsimony trees. Pseudomonas aeruginosa DSM $50071^{\top}$ (X06684) was used as an outgroup (not shown). Bar, 0.01 substitutions per nucleotide position. deepest branch, Pseudomonas migulae, in the neighbourjoining, Fitch-Margoliash and maximum-likelihood trees.

DNA-DNA hybridization was determined with a membrane filter technique (Seldin \& Dubnau, 1985) using the DIG High Prime DNA Labelling and Detection starter kit II (Roche). DNA-DNA relatedness levels among members of the subgroup of Pseudomonas cedrina CFML 96-198 were reported to be 26-44\% (Dabboussi et al., 1999; Verhille et al., 1999). DNA-DNA relatedness levels between strain CG20106 ${ }^{\mathrm{T}}$ and Pseudomonas migulae CIP $105470^{\mathrm{T}}$ and between strain CG20106 ${ }^{\mathrm{T}}$ and P. cedrina CFML $96-198^{\mathrm{T}}$ were 36 and $66 \%$, respectively, when their DNAs were used individually as labelled DNA probes for reciprocal hybridization experiments in duplicate. These DNA relatedness values, together with $16 \mathrm{~S}$ rRNA gene sequence-based analysis, indicate that strain CG20106 ${ }^{\mathrm{T}}$ represents a novel genomic species that is distinct from Pseudomonas migulae and Pseudomonas cedrina (Wayne et al., 1987).

Cells of strain CG20106 ${ }^{\mathrm{T}}$ and Pseudomonas azotoformans $\mathrm{KCCM} 35487^{\mathrm{T}}$ grown on NA at $30^{\circ} \mathrm{C}$ for 1 day were used for physiological and biochemical tests. Motility and flagella shape were examined by using phase-contrast microscopy (Axioskop 40; Zeiss) and transmission electron microscopy (JEM1010; JEOL), respectively. Growth temperature (5-50 ${ }^{\circ} \mathrm{C}$ with $5{ }^{\circ} \mathrm{C}$ intervals), $\mathrm{NaCl}$ tolerance $(0,1,2,3,5$, $10 \%, \mathrm{w} / \mathrm{v})$ and growth in an anaerobic chamber $\left(\mathrm{CO}_{2} / \mathrm{H}_{2} /\right.$ $\mathrm{N}_{2}, 10: 10: 80$; Sheldon Manufacturing) were checked using NA for up to 1 week. The production of water-soluble fluorescent pigments on King's B agar was determined as described previously (Smibert \& Krieg, 1994). For the determination of acetone production, test strains were grown in MRVP broth according to Smibert \& Krieg (1994). The Voges-Proskauer test was performed after $48 \mathrm{~h}$ incubation. Other physiological and biochemical test were performed using API 20E and API 20NE (bioMérieux) and Biolog GN2 (Biolog). Enzymic activities were tested using the API ZYM kit (bioMérieux) according to the manufacturer's instructions. Our ginseng isolate and Pseudomonas azotoformans KCCM $35487^{\mathrm{T}}$ had one or more flagella (see the supplementary figure available in IJSEM Online) and possessed many characteristics in common. Unless mentioned otherwise, the phenotypic characteristics of Pseudomonas azotoformans KCCM $35487^{\mathrm{T}}$ were the same as those of strain CG20106 ${ }^{\mathrm{T}}$. The results of the biochemical and physiological tests are given in the species description and in Table 1. As shown in Table 1, our isolate can be readily differentiated from other phylogenetically related pseudomonads by several phenotypic properties.

The chemotaxonomic characteristics of strain CG20106 ${ }^{\mathrm{T}}$ and Pseudomonas azotoformans KCCM $35487^{\mathrm{T}}$ were determined from cells grown at $28^{\circ} \mathrm{C}$ for 2 days on TSA medium (Merck). Analysis of the fatty acid methyl esters was performed by using GLC according to the instructions of the Microbial Identification System (MIDI). The major cellular fatty acids of strain CG20106 ${ }^{\mathrm{T}}$ were $\mathrm{C}_{16: 0}(27 \cdot 5 \pm 0 \cdot 7 \%)$, $\mathrm{C}_{16: 1} \omega 7 c$ and/or iso- $\mathrm{C}_{15: 0} 2-\mathrm{OH}(36 \cdot 4 \pm 0 \cdot 4 \%)$ (summed 
Table 1. Characteristics that differentiate strain CG20106 from other phylogenetically related species

Taxa: 1, strain CG20106 ${ }^{\mathrm{T}}$; 2, Pseudomonas azotoformans; 3, Pseudomonas migulae; 4, Pseudomonas cedrina; 5, Pseudomonas gessardii. Data are from this study and earlier studies (Dabboussi et al., 1999; Verhille et al., 1999). Symbols: +, positive reaction; - , negative reaction; $\mathrm{W}$, weakly positive; ND, not determined.

\begin{tabular}{|c|c|c|c|c|c|}
\hline Characteristic & 1 & 2 & 3 & 4 & 5 \\
\hline Growth at $3 \% \mathrm{NaCl}$ & + & + & + & + & - \\
\hline Growth at $5 \% \mathrm{NaCl}$ & + & + & - & - & - \\
\hline Gelatin liquefaction & + & - & - & ND & - \\
\hline Tween esterase & - & - & - & ND & + \\
\hline Urease & - & - & - & + & - \\
\hline Glucose acidification & + & - & ND & ND & ND \\
\hline Aesculin hydrolysis & + & - & $\mathrm{ND}$ & ND & ND \\
\hline \multicolumn{6}{|l|}{ Assimilation of: } \\
\hline myo-Inositol & + & + & - & + & + \\
\hline Phenylacetate & - & - & + & ND & - \\
\hline L-Arabinose & + & - & + & ND & - \\
\hline Adipate & - & + & $\mathrm{ND}$ & ND & ND \\
\hline D-Saccharate & + & + & + & ND & - \\
\hline meso-Erythritol & $\mathrm{w}$ & $\mathrm{w}$ & - & ND & + \\
\hline Adonitol & - & $\mathrm{w}$ & - & + & + \\
\hline D-Glucuronate & + & + & + & ND & - \\
\hline Itaconate & + & + & - & - & + \\
\hline L-Histidine & + & + & - & - & - \\
\hline Xylitol & - & $\mathrm{w}$ & - & ND & + \\
\hline D-Sorbitol & + & + & - & + & - \\
\hline D-Galactose & + & + & + & $\mathrm{ND}$ & - \\
\hline L-Arabitol & + & + & - & ND & + \\
\hline \multicolumn{6}{|l|}{ Fermentation of: } \\
\hline D-Glucose & + & - & ND & ND & ND \\
\hline L-Rhamnose & - & - & - & + & ND \\
\hline D-Sucrose & + & - & ND & - & ND \\
\hline D-Melibiose & + & - & - & - & - \\
\hline \multicolumn{6}{|l|}{ Enzymic profile (API ZYM) } \\
\hline Esterase-C4 & + & + & - & ND & + \\
\hline Leucine arylamidase & + & + & - & ND & + \\
\hline Naphthol-AS-BI-phosphohydrolase & $\mathrm{w}$ & + & ND & - & ND \\
\hline
\end{tabular}

feature 3$)$ and $\mathrm{C}_{18: 1} \omega 7 c(19 \cdot 4 \pm 0 \cdot 2 \%)$. In addition, $\mathrm{C}_{12: 0}$ $(3 \cdot 2 \pm 0 \cdot 1 \%), \mathrm{C}_{10: 0} \quad 3-\mathrm{OH} \quad(3 \cdot 3 \pm 0 \cdot 4 \%), \mathrm{C}_{12: 0} \quad 2-\mathrm{OH}$ $(3 \cdot 8 \pm 0 \cdot 0 \%), \quad \mathrm{C}_{12: 0} \quad 3-\mathrm{OH} \quad(3 \cdot 8 \pm 0 \cdot 3 \%)$ and $\mathrm{C}_{17: 0}$ cyclo $(1 \cdot 5 \pm 0 \cdot 2 \%)$ were detected. The major fatty acids of Pseudomonas azotoformans $\mathrm{KCCM} 35487^{\mathrm{T}}$ were $\mathrm{C}_{16: 0}(25 \cdot 6 \pm 0 \cdot 6 \%), \mathrm{C}_{16: 1} \omega 7 c$ and/or iso- $\mathrm{C}_{15: 0} 2-\mathrm{OH}$ $(33.9 \pm 1.5 \%)$ (summed feature 3 ) and $\mathrm{C}_{18: 1} \omega 7 c$ $(22 \cdot 7 \pm 0 \cdot 2 \%)$. In addition, $\mathrm{C}_{12: 0}(3 \cdot 9 \pm 0 \cdot 1 \%), \mathrm{C}_{18: 0}$ $(2 \cdot 5 \pm 0 \cdot 6 \%), \mathrm{C}_{10: 0} \quad 3-\mathrm{OH}(3 \cdot 2 \pm 0 \cdot 1 \%), \mathrm{C}_{12: 0} \quad 2-\mathrm{OH}$ $(2 \cdot 8 \pm 0 \cdot 1 \%)$ and $\mathrm{C}_{12: 0} 3-\mathrm{OH}(3 \cdot 5 \pm 0 \cdot 1 \%)$ were present. The $\mathrm{G}+\mathrm{C}$ content of the DNA was determined by using the thermal denaturation method of Marmur \& Doty (1962): the values for strains CG20106 ${ }^{\mathrm{T}}$ and Pseudomonas azotoformans KCCM $35487^{\mathrm{T}}$ were 61.4 and $61.0 \mathrm{~mol} \%$, respectively.
On the basis of the DNA-DNA relatedness and the formation of a distinctive phyletic line within the genus Pseudomonas in all trees inferred in this study, it is evident that strain CG20106 ${ }^{\mathrm{T}}$ can be assigned as a novel species of the genus Pseudomonas. In addition, a number of physiological and chemotaxonomic characteristics clearly distinguished our isolate from other phylogenetically related species (Table 1). Therefore, strain CG20106 ${ }^{\mathrm{T}}$ should be classified in a novel species within the genus Pseudomonas, for which the name Pseudomonas panacis sp. nov. is proposed.

\section{Description of Pseudomonas panacis sp. nov.}

Pseudomonas panacis (pa' na.cis. L. gen. n. panacis of panax, a fabulous plant supposed to heal all diseases, and the botanical genus name of ginseng).

Gram-negative, aerobic, rod-shaped and motile with one or more flagella. Catalase- and oxidase-positive. Colonies on NA are flat, translucent, butyraceous, beige-coloured with entire margins and usually $2-3 \mathrm{~mm}$ in diameter within 2 days at $30^{\circ} \mathrm{C}$. Spores are not formed. Grows between 4 and $35^{\circ} \mathrm{C}$, but not at $37^{\circ} \mathrm{C}$. Tolerates $\mathrm{NaCl}$ up to $5 \%$ on NA. Very poor growth detected under anaerobic conditions created by an anaerobic chamber $\left(\mathrm{CO}_{2} / \mathrm{H}_{2} / \mathrm{N}_{2}, 10: 10: 80\right)$. Produces fluorescent pigment on King's B medium. Reduces nitrate to nitrite and decomposes gelatin. Produces aesculin and arginine dihydrolases, but not urease, $\mathrm{H}_{2} \mathrm{~S}$, indole or acetone. Produces acid from D-glucose, D-sucrose, Dmelibiose and D-arabinose, but not from D-mannitol, D-sorbitol, inositol or amygdalin. Produces alkaline phosphatase, esterase (C4), esterase lipase (C8), leucine arylamidase, cystine arylamidase, trypsin, valine arylamidase and acid phosphatase, but not lipase (C14), $\alpha$-galactosidase, $\beta$-galactosidase, $\beta$-glucuronidase, $\alpha$ glucosidase, $\beta$-glucosidase, $N$-acetyl- $\beta$-glucosaminidase, $\alpha$ mannosidase, $\alpha$-fucosidase, lysine decarboxylase, ornithine decarboxylase or tryptophan deaminase. Naphthol-AS-BIphosphohydrolase and $\alpha$-chymotrypsin are weakly produced. Utilizes the following substrates as sole carbon and energy sources: glucose, arabinose, mannose, mannitol, $\mathrm{N}$ acetylglucosamine, gluconate, caprate, malate, malonate, citrate, D-fructose, $\alpha$-D-glucose, D-trehalose, methylpyruvate, cis-aconitic acid, citric acid, D-galactonic acid lactone, D-galacturonic acid, D-gluconic acid, $\beta$-hydroxybutyric acid, $p$-hydroxyphenylacetic acid, $\alpha$-ketoglutaric acid, DLlactic acid, propionic acid, D-saccharic acid, succinic acid, L-alanine, L-alanyl glycine, L-asparagine, L-aspartic acid, Lglutamic acid, L-ornithine, L-proline, L-pyroglutamic acid, L-serine, DL-carnitine, $\gamma$-aminobutyric acid, urocanic acid, inosine, uridine and glycerol. Does not utilize the following substrates: maltose, phenylacetate, $\alpha$-cyclodextrin, dextrin, glycogen, $\mathrm{N}$-acetyl-D-galactosamine, cellobiose, Lfucose, gentiobiose, $\alpha$-D-lactose, lactulose, maltose, Dmelibiose, methyl $\beta$-D-glucoside, D-raffinose, L-rhamnose, turanose, formic acid, $\alpha$-ketobutyric acid, $\alpha$-ketovaleric acid, sebacic acid, glucuronamide, glycyl-L-aspartic acid, hydroxy L-proline, L-phenylalanine, D-serine, thymidine, 
phenylethylamine, putrescine, 2,3-butanediol, glucose 1phosphate and glucose 6-phosphate. D-Psicose, D-alanine, D-glucosaminic acid, monomethyl succinate, acetic acid, $\alpha$-hydroxybutyric acid, $\gamma$-hydroxybutyric acid, bromosuccinic acid, succinamic acid, alaninamide, glycyl-Lglutamic acid, L-leucine, L-threonine and 2-aminoethanol are weakly utilized. Other phenotypic characteristics are given in Table 1. The major fatty acids are $\mathrm{C}_{16: 0}$ $(27 \cdot 5 \pm 0 \cdot 7 \%), \mathrm{C}_{16: 1} \omega 7 c$ and/or iso- $\mathrm{C}_{15: 0} 2-\mathrm{OH}(36 \cdot 4 \pm$ $0 \cdot 4 \%$ ) (summed feature 3 ) and $\mathrm{C}_{18: 1} \omega 7 c(19 \cdot 4 \pm 0 \cdot 2 \%)$. The DNA G $+\mathrm{C}$ content of the type strain is $61 \cdot 4 \mathrm{~mol} \%$.

The type strain, CG20106 ${ }^{\mathrm{T}}\left(=\mathrm{IMSNU} \quad 14100^{\mathrm{T}}=\mathrm{CIP}\right.$ $108524^{\mathrm{T}}=$ KCTC $12330^{\mathrm{T}}$ ), was isolated from the surface tissue of a rusty root lesion of Korean ginseng.

\section{Acknowledgements}

This work was supported by the 21C Frontier Microbial Genomics and Applications Center Program (grant MG02-0101-001-2-1-0) and the Strategic National R\&D Program through the Genetic Resources and Information Network (grant M1-0219-00-0018). This research was also supported by grant from the Basic Research Program (R01-2002000-00304-0) of the Korea Science and Engineering Foundation, and by the Brain Korea 21 Research Fellowship from the Ministry of Education and Human Resources Development.

\section{References}

Anzai, Y., Kudo, Y. \& Oyaizu, H. (1997). The phylogeny of the genera Chryseomonas, Flavimonas, and Pseudomonas supports synonymy of these three genera. Int J Syst Bacteriol 47, 249-251.

Chun, J. \& Goodfellow, M. (1995). A phylogenetic analysis of the genus Nocardia with $16 \mathrm{~S}$ rRNA gene sequences. Int J Syst Bacteriol 45, 240-245.

Chun, J., Bae, K. S., Moon, E. Y., Jung, S. O., Lee, H. K. \& Kim, S. J. (2000). Nocardiopsis kunsanensis sp. nov., a moderately halophilic actinomycete isolated from a saltern. Int J Syst Evol Microbiol 50, 1909-1913.

Dabboussi, F., Hamze, M., Elomari, M., Verhille, S., Baida, N., Izard, D. \& Leclerc, H. (1999). Taxonomic study of bacteria isolated from
Lebanese spring waters: proposal for Pseudomonas cedrella sp. nov. and P. orientalis sp. nov. Res Microbiol 150, 303-316.

Felsenstein, J. (1985). Confidence limits on phylogenies: an approach using the bootstrap. Evolution 39, 783-791.

Felsenstein, J. (1993). PHYLIP - Phylogenetic Inference Package, version 3.5.1. Seattle, WA: University of Washington.

Fitch, W. M. (1972). Toward defining the course of evolution: minimum change for a specific tree topology. Syst Zool 20, 406-416.

Fitch, W. M. \& Margoliash, E. (1967). Construction of phylogenetic trees. Science 155, 279-284.

Jukes, T. H. \& Cantor, C. R. (1969). Evolution of protein molecules. In Mammalian Protein Metabolism, pp. 21-132. Edited by H. N. Munro. New York: Academic Press.

Marmur, J. \& Doty, P. (1962). Determination of the base composition of deoxyribonucleic acid from its thermal denaturation temperature. J Mol Biol 5, 109-118.

Migula, W. (1894). Über ein neues System de Bakterien. Arb Bakteriol Inst Tech Hochsch Karlsruhe 1, 235-238 (in German).

Palleroni, N. J. (1993). Pseudomonas classification. A new case history in the taxonomy of gram-negative bacteria. Antonie van Leeuwenhoek 64, 231-251.

Saitou, N. \& Nei, M. (1987). The neighbor-joining method: a new method for reconstructing phylogenetic trees. Mol Biol Evol 4, 406-425.

Seldin, L. \& Dubnau, D. (1985). Deoxyribonucleic acid homology among Bacillus polymyxa, Bacillus macerans, Bacillus azotofixans, and other nitrogen-fixing Bacillus strains. Int J Syst Bacteriol 35, 151-154.

Smibert, R. M. \& Krieg, N. R. (1994). Phenotypic characterization. In Methods for General and Molecular Bacteriology, pp. 607-654. Washington DC: American Society for Microbiology.

Swofford, D. L. (1998). PAUP - Phylogenetic Analysis Using Parsimony, version 4. Sunderland, MA: Sinauer.

Verhille, S., Baïda, N., Dabboussi, F., Hamze, M., Izard, D. \& Leclerc, H. (1999). Pseudomonas gessardii sp. nov. and Pseudomonas migulae sp. nov., two new species isolated from natural mineral waters. Int J Syst Evol Microbiol 49, 1559-1572.

Wayne, L. G., Brenner, D. J., Colwell, R. R. \& 9 other authors (1987). International Committee on Systematic Bacteriology. Report of the ad hoc committee on reconciliation of approaches to bacterial systematics. Int J Syst Bacteriol 37, 463-464. 